\title{
THE EUROPEAN UNION'S COHESION POLICY AND THE ECONOMIC SECURITY OF POLAND
}

In 1989 Poland commenced the political, social and economic transformations process. It also began its efforts seeking European integration. Two parallel processes were underway in our Poland. One entailed restructuring of the state. The other - such a reconstruction thereof which would stand up to the test of European integration, which became reality on 1 May 2004. Polish successful accession was the start of another phase of the process constituting in shortening the developmental gap between Poland and West European countries. Yet membership in the European Union allowed Poland to reach out to the European budget for funds, amongst which two sources played a key role in the building of the country's socio-economic potential. The first, numerically greater, supporting development were and are funds designated for the performance of the European cohesion policy. With funds designated for the performance of the Common Agricultural Policy as the second source. However, it should be emphasised that the discussions in this article focus on means designated for the performance of the cohesion policy, which directly and indirectly contribute to the creation of Polish socio-economic potential, and as such make it possible to lessen the developmental gap between European Union states. Thus we may ascertain that the money originating from EU's budget contributes to the creation and preservation of the Poland's economic security. Experts on the subject highlight that ensuring economic security is one of the fundamental aims of domestic and foreign policy. At the same time they point out that in the short term it is exactly on this plane that countries will engage in rivalry. Simultaneously they suggest that the said rivalry may intensify and subsequently lead to tensions on an international scale. Katarzyna Żukrowska points out that economic security was always significant in determining the security sphere of every state. She also points out that the economy and its condition are decisive in all spheres of security: military, political and social. Pointing out the associations between the latter and raw material security, including those for the power industry, water, appropriate levels of education, application of the right financial and monetary policy as well as polices conducive to an effective use of resources which a given economy, or a country has at its disposal and which are decisive to its development (Żukrowska, 2011: 1).

Konrad Raczkowski in his article (Raczkowski, 2012) defines a country's economic security as endogenously and exogenously relatively balanced state of the functioning if the national economy. At the same time, it is necessary to add that the inherent risk of disruptions to the balance is maintained within defined and acceptable organisational and legal norms as well as social interaction rules (ibidem: 81). Whereas by economic 
security Krzysztof M. Księżopolski understands an undisturbed functioning of economies, or maintaining the basic development indicators and providing a comparative balance with the economies of other states (Księżopolski, 2011: 32). Finally, Katarzyna Żurkowska assumes that we may talk about economic security of an economy when the economy maintains a relatively high rate of development, guaranteeing a low rate of unemployment and stability in national finances. To be more precise she adds that in a European Union member state, such as Poland, these conditions are precisely defined by the convergence criteria, as well as by the Stability Pact. In fact this pertains to maintaining such conditions in an economy for economic growth not to exert upward pressure on the rate of unemployment but rather lead to its decrease, and for the budget deficit not to exceed 3\% of GDP - and rather for it to return a surplus, for the national debt to be at a level below $60 \%$ of GDP and for inflation and interest rates to be low (Żukrowska, 2011: 2-3).

\section{EFFECTS OF THE EU FUNDS ON POLISH GROWTH IN 2004-2009}

As was pointed out right at the outset, the aim of regional policy is a harmonious development of regions and achieving structural cohesion across the entire EU. Polish accession meant that national regional policy is now seen in a much wider context. Poland absorbs significant funds designated for the creation and conduct of regional policy. Acquiring and appropriate use of these funds is in the best interest of Poland (Ciak, Adamiak, 2007: 9). In this context as is highlighted by authors of the Regional development in Europe. Territorial cohesion EU budget overview report, in recent years the approach to regional policy has undergone a significant change in Poland. The initial stimuli were supplied by the EU accession process, the influx of Union structural funds as well as the management and implementation of programmes financed by them. It was so that these funds could be used and addressed in an justified and meaningful manner within defined time horizons appropriate Polish regional policy strategic objectives were set. During 2000-2006 the primary strategic documents were the National Regional Development Strategy 2001-2006 (NSRR) and the National Development Plan 2004-2006 (NPR). The NSRR defines the objectives, priorities and criteria for the selection of support areas used do define the financial support granted to particular regions. It was a framework document encompassing financial interventions from the national budget, pre-accession funds and foreign investments. Whereas the NPR 2004-2006 defined the strategic framework for the socio-economic development of Poland, also constituting a basis for negotiation the amount of aid for Poland granted by the EU within the scope of structural funds and the Cohesion Fund. The NPR also defined the basis for drawing up the Basis for Community help afforded top Poland which indicated the directions and level of financing for EU fund interventions during 2004-2006. It should be noted that the NPR a large extent shaped using the achievements of the development strategy and in particular from the NSRR. Thus NSRR as well as NPR reflect the temporary manner of perceiving challenges faced by regional policy. A strategic goal of the regional development policy during that time was supporting regional economic development and prevention of some re- 
gions becoming obscure and marginalised. Objectives geared towards efficiency through supporting growth factors in all regions, which included: development of export potential, human capital abilities, entrepreneurship, the ability to draw and maintain production factors from outside the region (Gorzelak, 2007: 180-183). Poland received 12.8 billion euro from the EU for the performance of the National Development Plan $(N D P)$. These funds supported the performance of projects within the scope of: European Fund for Regional Development, European Social Fund, European Agricultural Guarantee Fund and European Fisheries Fund and Cohesion Fund (Tab. 1).

Table 1

The allocations for structural operations in Poland in 2004-2006 (by support instruments)

\begin{tabular}{||l|c|c|c|c||}
\hline \multirow{2}{*}{\multicolumn{1}{|c}{ Support area }} & \multicolumn{4}{|c|}{$\begin{array}{c}\text { The allocations for structural operations for Poland } \\
\text { (in euro million, prices as of 2004) }\end{array}$} \\
\cline { 2 - 5 } & total & $\mathbf{2 0 0 4}$ & $\mathbf{2 0 0 5}$ & $\mathbf{2 0 0 6}$ \\
\hline Cohesion Fund (average) & $4,178.8$ & $1,414.6$ & $1,170.6$ & $1,593.4$ \\
\hline Structural funds & $8,275.8$ & $1,933.6$ & $2,762.7$ & $3,579.5$ \\
\hline Community Initiatives & \multicolumn{5}{|c||}{} \\
\hline INTERREG & 221.4 & 61.8 & 70.0 & 89.5 \\
\hline EQUAL & 133.9 & 31.8 & 44.8 & 57.3 \\
\hline Structural operations in total & $8,631.1$ & $2,027.2$ & $2,877.6$ & $3,726.3$ \\
\hline Total & $\mathbf{1 2 , 8 0 9 . 9}$ & $\mathbf{3 , 4 4 1 . 8}$ & $\mathbf{4 , 0 4 8 . 2}$ & $\mathbf{5 , 3 1 9 . 7}$ \\
\hline
\end{tabular}

Source: T. G. Grosse, Polityka regionalna Unii Europejskiej. Przykład Grecji, Włoch, Irlandii i Polski, Warszawa 2004, p. 262.

The targets defined in the NPR, the available amounts transferred from the EU budget determined both the number as well as the structure of the approved operational programmes and those still of the drawing board. Seven operational programmes were active at that time. Their detailed list and funds designated for their performance are depicted in Fig. 1.

In total starting from the moment operational programmes were set into motions within the scope of the National Development Plan 2004-2006, more than 88.6 thousand projects were executed. The data contained in the Effect of European funds on the economy of Polish regions and convergence with EU countries. 2010 Report points to the fact that the participation of particular types of projects according to value was as follows. The largest projects constituted primary infrastructure projects - in excess of 58.9 billion PLN. They had a $57.7 \%$ share in the value of implemented projects. The next group were production sector projects $-29.9 \%$, and expenditures designated for the development of human resources constituted $11.1 \%$ of the overall value of all projects. The value of technical service projects stood at $1.25 \%$ of the total value of projects (Wpływ, 2010: 32). Detailed data as to the structure of implemented projects according to the main structural expenditures classification categories are presented in Tab. 2. 


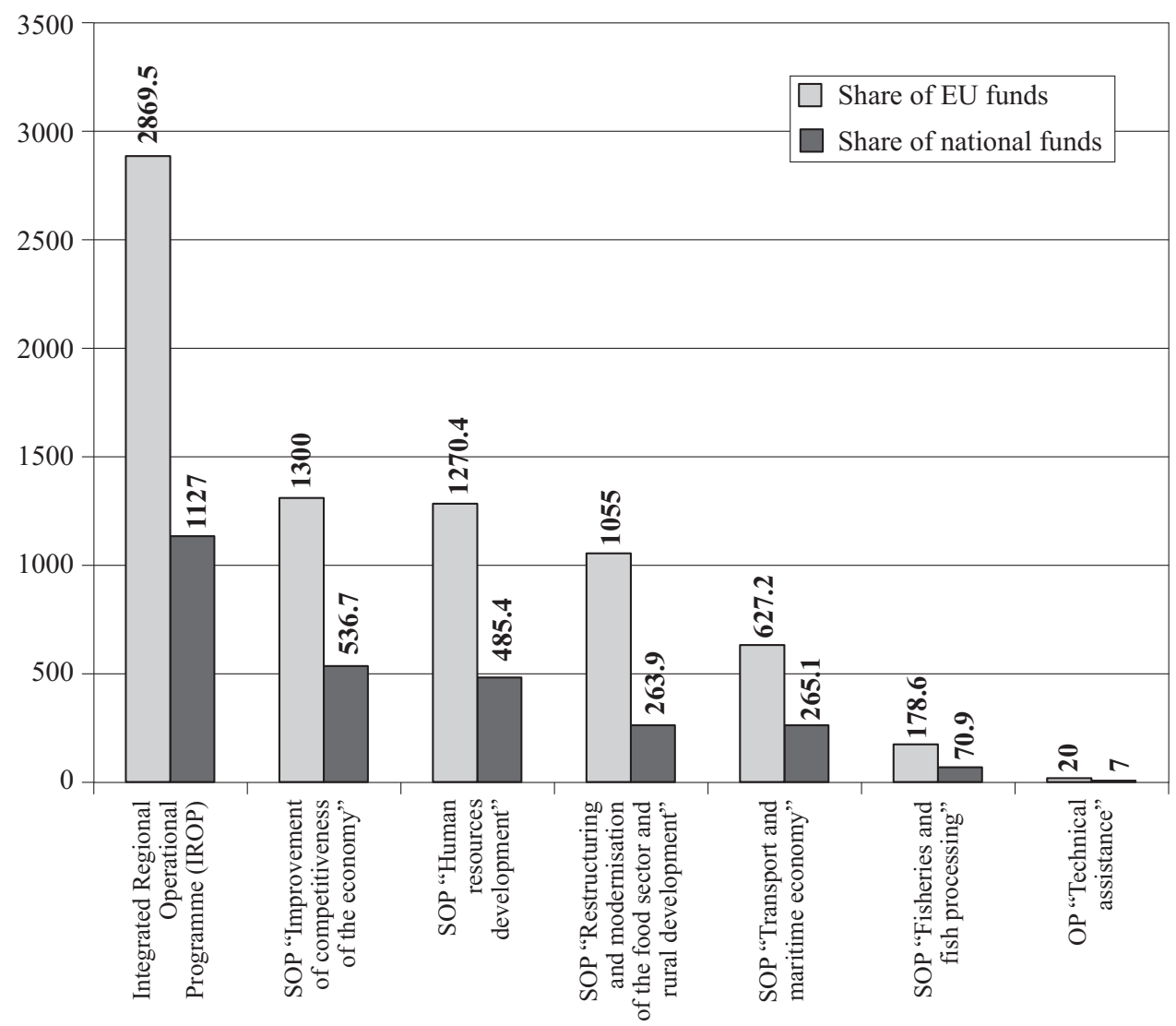

Fig. 1. Share of the EU and national funds in the financing of particular operational programmes (in million euro)

Source: National Development Plan 2004-2006 (2003), Council of Ministers, Warsaw, p. 94.

Table 2

Value and structure of implemented projects according to the main structural classification categories within the scope of NPR 2004-2006 (in PLN \%)

\begin{tabular}{||l|c|c|c|c||}
\hline \hline & $\begin{array}{c}\text { Value } \\
\text { of projects }\end{array}$ & $\begin{array}{c}\text { Value of } \\
\text { co-financing }\end{array}$ & $\begin{array}{c}\text { Value } \\
\text { structure }\end{array}$ & $\begin{array}{c}\text { Support } \\
\text { structure }\end{array}$ \\
\hline Production sector & $30,530,741,681.96$ & $10,700,920,611.32$ & $29.90 \%$ & $18.38 \%$ \\
\hline Human resources & $11,342,025,043.62$ & $8,098,368,463.02$ & $11.11 \%$ & $13.91 \%$ \\
\hline Infrastructure primary & $58,947,870,641.00$ & $38,519,451,981.76$ & $57.74 \%$ & $66.16 \%$ \\
\hline Technical Support & $1,274,889,401.32$ & $899,116,547.02$ & $1.25 \%$ & $1.54 \%$ \\
\hline Total & $\mathbf{1 0 2 , 0 9 5 , 5 2 6 , 7 6 7 . 9 0}$ & $\mathbf{5 8 , 2 1 7 , 8 5 7 , 6 0 3 . 1 3}$ & $\mathbf{1 0 0 . 0 0 \%}$ & $\mathbf{1 0 0 . 0 0 \%}$ \\
\hline
\end{tabular}

Source: Wplyw funduszy europejskich na gospodarkę polskich regionów i konwergencje z krajami UE. Raport 2010 (2010), Ministerstwo Rozwoju Regionalnego, Warszawa, p. 32.

Analysing project performance in 2004-2006 within the scope of NPR is should be noted that the value of co-financing reached $57 \%$ of the total value of projects. The 
structure of aid granted for the implementation of projects within the scope of that time scale was as follows: most funds $66 \%$ from structural funds and the Cohesion Fund were designated for implementation of projects within the scope of infrastructure development. Markedly less, as only $18 \%$ of funds were designated to support the production sector. Whereas the development of human resources was supported by $14 \%$ of all the funds. The smallest share of the money originating from the EU budget was designated for the implementation of technical service projects $-1.5 \%$ (ibidem).

The structure of performed projects according to structural expenditures classification subcategories shows the main areas where projects of the largest overall value are performed. They include: transport infrastructure, environmental infrastructure, agriculture and business support (ibidem) - table 3.

Table 3

Value of implemented projects according to the structural expenditures classification subcategories within the scope of NPR 2004-2006

\begin{tabular}{|c|c|c|}
\hline Intervention area & Value of projects (in PLN) & Structure \\
\hline Agriculture & $9,453,753,591.88$ & $9.26 \%$ \\
\hline Forestry & $55,229,667.97$ & $0.05 \%$ \\
\hline Planning adaptations and development of rural areas & $2,515,007,174.26$ & $2.46 \%$ \\
\hline Fishing & $1,584,144,232.52$ & $1.55 \%$ \\
\hline Large enterprises & $4,556,220,886.71$ & $4.46 \%$ \\
\hline Small and medium enterprises & $9,601,060,068.65$ & $9.40 \%$ \\
\hline Tourism & $1,443,546,292.99$ & $1.41 \%$ \\
\hline $\mathrm{R} \& \mathrm{D}$ & $1,321,779,766.98$ & $1.29 \%$ \\
\hline Job market policy & $3,402,009,458.96$ & $3.33 \%$ \\
\hline Social exclusion & $1,135,065,952.90$ & $1.11 \%$ \\
\hline Professional education & $4,296,101,062.74$ & $4.21 \%$ \\
\hline Training at enterprises & $2,189,978,002.47$ & $2.15 \%$ \\
\hline Actions to support females on the job market & $318,870,566.55$ & $0.31 \%$ \\
\hline Transport Infrastructure & $32,112,969,063.40$ & $31.45 \%$ \\
\hline Telecommunication infrastructure and IT community & $1,094,127,828.88$ & $1.07 \%$ \\
\hline Power infrastructure & $34,833,078.75$ & $0.03 \%$ \\
\hline Environmental infrastructure & $20,504,329,497.60$ & $20.08 \%$ \\
\hline Spatial planning and revitalisation & $2,242,941,097.16$ & $2.20 \%$ \\
\hline Social infrastructure & $2,958,670,075.20$ & $2.90 \%$ \\
\hline Other & $1,274,889,401.32$ & $1.25 \%$ \\
\hline Total & $102,095,526,767.90$ & $100.00 \%$ \\
\hline
\end{tabular}

Source: Wplyw funduszy europejskich na gospodarkę polskich regionów i konwergencję z krajami UE. Raport 2010 (2010), Ministerstwo Rozwoju Regionalnego, Warszawa, p. 32.

The Effect of European funds on the economy of Polish regions and convergence with EU countries. Report 2010 publication highlighted that the structure of the co-financing value from Union funds stemming from concluded agreements with beneficiaries is similar to the value of executed investments. Also here the largest support 
amounts were granted in the transport infrastructure and environmental infrastructure areas. In total, 34.8 billion $\mathrm{zł}$ was designated for their performance, which constituted $59.9 \%$ of the entire co-financing value from EU funds. $6 \%$ of funds were designated for SME development and farmers received 5.2\% of the funds transferred to Poland during that period. Profession education and an improvement in staff adaptability were also supported using funds from the EU budget. Here the level of aid oscillated around the $5.3 \%$ level. Unfortunately the R\&D sector or the development of the information society or event ICT were not significantly co-financed. Such a stet of things may have a detrimental effect on the achievement of goals defined by the Lisbon Strategy. Detailed co-financing values for particular budget classification subcategories are shown in table 4.

Table 4

Value of co-financing using assets from the EU budget for projects according to the structural expenditures classification subcategories within the scope of NPR 2004-2006

\begin{tabular}{|c|c|c|}
\hline Intervention area & Value of projects (in PLN) & Structure \\
\hline Agriculture & $3,049,945,811.97$ & $5.24 \%$ \\
\hline Forestry & $42,279,992.63$ & $0.07 \%$ \\
\hline Planning adaptations and development of rural areas & $1,387,351,636.76$ & $2.38 \%$ \\
\hline Fishing & $728,753,976.95$ & $1.25 \%$ \\
\hline Large enterprises & $647,463,734.36$ & $1.11 \%$ \\
\hline Small and medium enterprises & $3,539,697,149.65$ & $6.08 \%$ \\
\hline Tourism & $616,762,872.87$ & $1.06 \%$ \\
\hline R\&D & $688,665,436.14$ & $1.18 \%$ \\
\hline Job market policy & $2,498,100,100.31$ & $4.29 \%$ \\
\hline Social exclusion & $820,962,391.71$ & $1.41 \%$ \\
\hline Professional education & $3,133,707,993.32$ & $5.38 \%$ \\
\hline Training at enterprises & $1,410,996,875.35$ & $2.42 \%$ \\
\hline Actions to support females on the job market & $234,601,102.34$ & $0.40 \%$ \\
\hline Transport Infrastructure & $21,440,564,831.96$ & $36.83 \%$ \\
\hline Telecommunication infrastructure and IT community & $754,276,202.79$ & $1.30 \%$ \\
\hline Power infrastructure & $17,984,123.14$ & $0.03 \%$ \\
\hline Environmental infrastructure & $13,447,484,834.86$ & $23.10 \%$ \\
\hline Spatial planning and revitalisation & $1,181,410,334.68$ & $2.03 \%$ \\
\hline Social infrastructure & $1,667,731,654.32$ & $2.88 \%$ \\
\hline Other & $899,116,547.02$ & $1.54 \%$ \\
\hline Total & $58,217,857,603.13$ & $100.00 \%$ \\
\hline
\end{tabular}

Source: Wplyw funduszy europejskich na gospodarkę polskich regionów i konwergencję z krajami UE. Raport 2010 (2010), Ministerstwo Rozwoju Regionalnego, Warszawa, p. 33.

Analysing the share of particular voivodeships in the distribution of European Union budget funds within the scope of the National Development Plan 2004-2006 significant differences should be identified. The most European funds within the scope of all programmes available at that time found their way to the richest voivodeships, which 
are home to the largest populations. Amongst others, this situation is a consequence of an assumed algorithm ${ }^{1}$ for the division of funds within the scope of the Integrated Regional Development Programme.

Table 5

Regional distribution of support granted within the scope of NPR 2004-2006

\begin{tabular}{||l|c|c|c||}
\hline \multicolumn{1}{|c|}{ Voivodeship } & $\begin{array}{c}\text { Value of projects } \\
\text { (in PLN) }\end{array}$ & $\begin{array}{c}\text { Co-financing } \\
\text { value (in PLN) }\end{array}$ & $\begin{array}{c}\text { Co-financing } \\
\text { structure }\end{array}$ \\
\hline Dolnośląskie & $7,997,565,008.47$ & $4,968,147,366.95$ & $8.5 \%$ \\
\hline Kujawsko-pomorskie & $4,711,793,827.09$ & $2,389,364,245.01$ & $4.1 \%$ \\
\hline Lubelskie & $4,095,784,898.21$ & $2,155,038,369.74$ & $3.7 \%$ \\
\hline Lubuskie & $2,320,783,533.39$ & $1,335,350,061.32$ & $2.3 \%$ \\
\hline Lódzkie & $6,585,477,496.16$ & $3,333,973,913.80$ & $5.7 \%$ \\
\hline Małopolskie & $5,300,485,637.82$ & $2,951,288,360.39$ & $5.1 \%$ \\
\hline Mazowieckie & $16,784,043,133.58$ & $9,281,787,941.41$ & $15.9 \%$ \\
\hline Opolskie & $1,809,724,099.50$ & $1,037,544,494.46$ & $1.8 \%$ \\
\hline Podkarpackie & $3,410,570,460.08$ & $1,983,287,413.13$ & $3.4 \%$ \\
\hline Podlaskie & $2,499,892,604.80$ & $1,199,186,013.84$ & $2.1 \%$ \\
\hline Pomorskie & $5,906,935,574.82$ & $3,204,227,195.01$ & $5.5 \%$ \\
\hline Śląskie & $12,656,232,691.56$ & $7,237,458,058.48$ & $12.4 \%$ \\
\hline Świętokrzyskie & $2,467,235,564.32$ & $1,188,775,895.33$ & $2.0 \%$ \\
\hline Warmińsko-mazurskie & $3,678,750,914.37$ & $2,006,020,697.69$ & $3.4 \%$ \\
\hline Wielkopolskie & $7,873,979,772.30$ & $4,400,733,547.90$ & $7.6 \%$ \\
\hline Zachodniopomorskie & $5,537,343,329.74$ & $3,233,161,749.18$ & $5.6 \%$ \\
\hline National level & $8,508,928,221.89$ & $6,312,512,279.49$ & $10.8 \%$ \\
\hline Total & $\mathbf{1 0 2 , 0 9 5 , 5 2 6 , 7 6 8 . 0 8}$ & $\mathbf{5 8 , 2 1 7 , 8 5 7 , 6 0 3 . 1 3}$ & $\mathbf{1 0 0 . 0 0 \%}$ \\
\hline
\end{tabular}

Source: Wplyw funduszy europejskich na gospodarkę polskich regionów i konwergencję z krajami UE. Raport 2010 (2010), Ministerstwo Rozwoju Regionalnego, Warszawa, p. 33.

It is clear from the above data that most structural funds and Cohesion Fund means found their way to voivodeships such as mazowieckie, śląskie, dolnośląskie and wielkopolskie. It is worth pointing out that the five richest voivodeships obtained half the available funds executed within the scope of NPR 2004-2006. Voivodeships in

1 An algorithm based on three criteria was used to distribute the funds: (1) Assuming that Poland as a whole complies with the qualifying criteria for areas covered by EU structural funds Objective 1, the dominant role of the population criterion was justified in the regional distribution of the support means. In such a context $80 \%$ of the means were distributed proportionally to the numbers of residents in particular voivodeships; (2) Taking into consideration the inter-voivodeship differences in the levels of GDP per capita, $10 \%$ of the means were distributed proportionally to the number of residents of a voivodeship where the average value of GDP per capita in 1997-1999 was less than $80 \%$ of the average per capita GDP in Poland; (3) A high unemployment rate constituting a risk in come counties (powiat) of permanent marginalisation of social groups caused that $10 \%$ of the support means were designated fro those counties, where the average rate of unemployment in 1999-2001 exceeded 150\% of the national average. Integrated Regional Operational Development Plan (ZPORR 2004-2006) (2003), Ministerstwo Gospodarki, Pracy i Polityki Społecznej, Warsaw, p. 53. 
Eastern Poland received 15\% of the funds. In analysing the distribution of means obtained by the regions in terms of particular intervention categories, it turns out that voivodeships with the largest socio-economic potential: śląskie, mazowieckie, dolnośląskie designated almost $80 \%$ of the means for development of infrastructure. Whereas voivodeships in East Poland spent approx. $50 \%$ of the funds on investments of this type.

Works on a new perspective were preceded by an in-depth debate on the possible reformulation of the current approach adopted with respect of the cohesion policy implemented in Poland, so as to maximise the effectiveness of European means in conditions right for the level of socio-economic development of the countries participating in the said policy. Grzegorz Gorzelak made it clear that the approach to the most important development factors changes not only depending on the theoretical models, but also depending on the developmental stage of particular economies and societies. He also pointed out that over the centuries an evolution occurred from considering natural resources as the foundation for development, through capital and political clout, technology and knowledge to the currently formulated hypotheses seeking the roots of development in institutional and cultural factors (Gorzelak, 2007: 184).

Instigating works on the new 2007-2013 programming period afforded the possibility for another evaluation of the political objectives. As a result changes were introduced both the European Union as well as national level. The fundamental document at EU level is the Strategic Community Guidelines which define the strategic development directions in the forthcoming financial perspective. Among the defined objectives one finds the following: transforming Europe and its regions into an area most interesting for investors and potential employees; creating more and better jobs; development of knowledge and innovation for the sake of economic growth; furnishing a territorial dimension to the cohesion policy (Wokót, 2008: 61). Revising the political objectives, also in light of the experiences and projects undertaken thus far in Poland a strategic document was adopted, constituting the foundation for programming the cohesion policy for the forthcoming seven years. The National Development Strategy 2007-2015 is the said document. The strategy sets out the objectives and priorities for socio-economic development in Poland and the conditions which should facilitate the said development. Among the priority areas requiring financial support from structural funds and the Cohesion Fund one finds such issues as: improving innovation and competitiveness of the economy; improving the condition of primary infrastructure (technical and social); increase in employment levels and quality; creation of an integrated community, security system and principles for cooperation; regional development and improving territorial cohesion (Strategia, 2006: 4-10). The strategy constituted the basis for drawing up the National Strategic Frame of Reference. The documents describing development objectives adopted by the Government of Poland for implementation in 2007-2013. However, applying the $n+2$ principle the projects could actually be implemented in terms of financing and actual performance until 2015. Amongst them, the primary in terms of creating socio-economic development are: creating conditions for maintaining a stable and high economic growth; increasing employment through the development of human and social capital; improving the competitiveness of Polish business; construction and modernisation of technical infrastructure; improving the competitiveness of Polish regions, development of rural areas, prevention of their marginalisation 
(Narodowe, 2007: 5). The development objectives as defined above, which are also a result of an assessment of the social and economic situation, have allowed for an adoption of such a structure of operational programmes which will facilitate their achievement on schedule. With shaping operational programmes financed from the $E u$ ropean Fund for Regional Development, the European Social Fund and the Cohesion Fund the initial experiences stemming from the performance of the previous financial perspective in 2004-2006 were used. As a consequence in 2007-2013 next to European Territorial Cooperation programmes, 16 regional operational programmes were being put together as well as four horizontal programs - performed across the entire country - which comprised: Infrastructure and Environment Operational Programme, Human Capital Operational Programme, Innovative Technical Support Operational Programme. The last of the operational programmes implemented during that period is the East Poland Development Operational Programme (Babiak, 2008: 23). Globally for NSFR in 2007-2013 will amount to 67.3 billion euro. Out of that amount more than 66.5 billion euro was designated for co-financing Objective 1 operational programmes - convergence, whereas the amount of 557.7 million euro was designated to perform the European Territorial Cooperation programmes. Additionally more than 173.3 million euro was designated to perform transborder cooperation programmes within the scope of the European Neighbourhood and Partnership Instrument participated in by Poland. Furthermore it should be added that within the scope of Objective 1 of the European cohesion policy - "Convergence" $67 \%$ of the means originates from structural funds ( $52 \%$ from EFRD, $15 \%$ from ECF). The remaining 33\% originates from the Cohesion Fund. Within the scope of allocation, the European Council designated financial funds in the amount exceeding 992 million euro from the EFRD for 5 regions of Poland, where GDP per capita (according to Eurostat 2002 data) is the lowest in the entire EU. These are voivodeships: lubelskie, podkarpackie, podlaskie, świętokrzyskie, warmińsko-mazurskie (Narodowe, 2007: 116) - Figure 2.

Implementing and executing five national and sixteen regional operational programmes began in 2008. From an analysis of the KSI SIMIK database it is clear that until the end of 2009 almost 29 thousand agreements were concluded for the execution of projects representing a total value of 114.9 billion PLN. A detailed analysis of the granted support in 2007-2009 in terms of regions shows that the largest value agreements were concluded in Śląskie and Mazowieckie voivodeships. Their total number represented $25 \%$ of the value of all agreements concluded to date. Wielkopolskie, małopolskie and dolnośląskie voivodeships were next. Relatively small value agreements, and a resulting small scale support were concluded in kujawsko-pomorskie, opolskie and świętokrzyskie voivodeships. However, such a picture of the granted support does not take into consideration the fact that nominal access to funds, particularly within the scope of regional programmes is highly differentiated. The value of particular regional programmes is a consequence of the adopted algorithm for distributing the funds which was described together with the 2004-2006 financial perspective. Nevertheless, it should be pointed out that in 2009 a significant intensification of expenditures was noted. It is also evident that the funds available within the scope of the cohesion policy in 2007-2013, due to which numerous undertakings were co-financed were of significance for the easing of the consequences of the economic slowdown in 


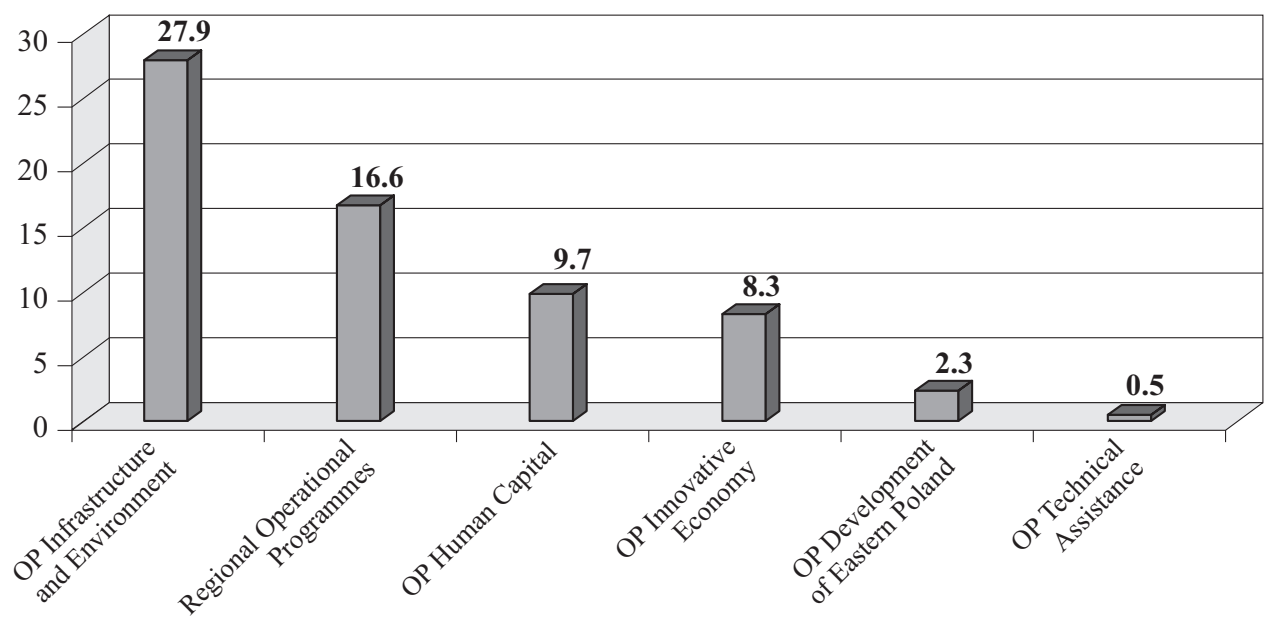

Fig. 2. Distribution of structural funds and the cohesion fund in Poland in terms of particular operational programmes (in billion euro)

Source: National Cohesion Strategy 2007-2013 (2007), Ministerstwo Rozwoju Regionalnego, Warszawa, p. 116.

Poland. According to Regional Development Ministry data, almost half of the growth rate in 2009 was possible on account of European intervention (tab. 6).

Value of granted support according in terms of territories in 2007-2009 (in PLN)

\begin{tabular}{|l|c|c|c||}
\hline \multicolumn{1}{|c|}{ Voivodeship } & $\begin{array}{c}\text { Value of projects } \\
\text { (in PLN) }\end{array}$ & $\begin{array}{c}\text { Co-financing } \\
\text { value (in PLN) }\end{array}$ & $\begin{array}{c}\text { Co-financing } \\
\text { structure }\end{array}$ \\
\hline The entire country & $14,476,351,169.66$ & $11,617,104,777.00$ & $16.13 \%$ \\
\hline Dolnośląskie & $7,580,761,096.15$ & $4,212,983,514.54$ & $5.85 \%$ \\
\hline Kujawsko-pomorskie & $3,859,376,547.36$ & $2,006,690,244.40$ & $2.79 \%$ \\
\hline Lubelskie & $4,255,009,561.68$ & $2,583,724,765.10$ & $3.59 \%$ \\
\hline Lubuskie & $4,203,901,442.88$ & $2,412,723,808.56$ & $3.35 \%$ \\
\hline Lódzkie & $5,980,891,933.82$ & $3,619,733,339.95$ & $5.03 \%$ \\
\hline Małopolskie & $7,892,628,644.82$ & $4,759,290,535.95$ & $6.61 \%$ \\
\hline Mazowieckie & $14,108,828,858.76$ & $8,858,911,464.70$ & $12.30 \%$ \\
\hline Opolskie & $2,535,154,133.02$ & $1,237,375,052.21$ & $1.72 \%$ \\
\hline Podkarpackie & $4,923,648,616.86$ & $3,125,088,695.29$ & $4.34 \%$ \\
\hline Podlaskie & $3,267,351,531.91$ & $1,984,885,834.58$ & $2.76 \%$ \\
\hline Pomorskie & $6,152,367,381.30$ & $3,584,157,018.49$ & $4.98 \%$ \\
\hline Śląskie & $16,247,741,035.08$ & $10,512,856,384.87$ & $14.60 \%$ \\
\hline Świętokrzyskie & $3,229,656,898.61$ & $1,857,903,920.27$ & $2.58 \%$ \\
\hline Warmińsko-mazurskie & $4,750,898,034.42$ & $2,775,400,264.85$ & $3.85 \%$ \\
\hline Wielkopolskie & $6,527,713,790.89$ & $3,769,506,281.20$ & $5.23 \%$ \\
\hline Zachodniopomorskie & $4,951,508,153.87$ & $3,107,229,344.39$ & $4.31 \%$ \\
\hline Total & $\mathbf{1 1 4 , 9 4 3 , 7 8 8 , 8 3 1 . 0 9}$ & $\mathbf{7 2 , 0 2 5 , 5 6 5 , 2 4 6 . 3 4}$ & $\mathbf{1 0 0 . 0 0 \%}$ \\
\hline \hline
\end{tabular}

Source: Wplyw funduszy europejskich na gospodarkę polskich regionów i konwergencję z krajami UE. Raport 2010 (2010), Ministerstwo Rozwoju Regionalnego, Warszawa, p. 35. 
The authors of the Regional growth in Poland. Report 2009 report highlight that the course of economic processes in Poland during the period subject to analysis on the one hand was affected by the international economic cycle, which, in light of the increasing openness of the economy and globalisation process - the economy of our country is dependent upon and on the other by the Polish accession to the European Union. Despite fluctuations the growth rate throughout the period was positive, which facilitated further external convergence, meaning a decrease in the distance between our country and the EU. Differences in the development of individual voivodeships should be pointed out, which despite the external convergence contributed to a further deepening of disproportions on the developmental level, both interregional as well as inside particular regions. It should be pointed out that in 2007, as compared to 1999 Polish GDP was $37.5 \%$ higher (in constant prices). It should also be added that the average rate of growth in 2000-2007 amounted to 4.1\% out of which in 2000-2003 the rate of growth was just $2.7 \%$ and in 2004-2007 reached 5.4\%. It is very beneficial that all voivodeships reported economic growth both in 2000-2003 as well as in 2004-2006, whereas ion the post-accession period it was much faster and decisive for the development in the entire country in 2000-2006. Mazowieckie voivodeship was in the lead followed by wielkopolskie, małopolskie, and then thanks to rapid growth in 2004-2006 dolnośląskie voivodeship as well. Whereas a much slower rate of growth than the average was reported in the following voivodeships: lubelskie, podkarpackie and opolskie. In the time horizon under discussion zachodniopomorskie voivodeship reported slowest growth, whose per capita level of development in 1999 was still ahead of the national average, however in subsequent years fell below the national average. Furthermore, it should be pointed out that in the initial years after accession to the European Union the largest growth rate acceleration - by more than $4 \%$ an average per annum - was reported by voivodeships such as: lubuskie, dolnośląskie and opolskie which in the pre-accession period developed very slowly. The smallest - of less that $1 \%$ - acceleration was reported by podlaskie and lubelskie as well as warmińsko-mazurskie voivodeships. The differentiated growth rates caused changes with respect to per capita GDP with reference to the national average. In 2000-2006, for mazowieckie dolnośląskie, łódzkie, wielkopolskie and małopolskie voivodeships this ratio increased and decreased for all others, particularly markedly - by more than $10 \%$ - for Zachodniopomorskie voivodeship. The decrease was in the region of $0.2-3.4 \%$ for the other regions (Gorzelak, 2007: 25-26). Whereas analyses of 2004-2008 show that the largest increase in GDP (in constant prices) occurred in the following voivodeships: mazowieckie, lubuskie and pomorskie. The leaders in 2008 were the voivodeships which reported economic growth in excess of 7\%: podkarpackie 7.3\%, łódzkie and śląskie at $7.1 \%$, świętokrzyskie $6.8 \%$ and lubelskie $6.7 \%$. The lowest growth in 2008 was represented by the following voivodeships: opolskie $0.6 \%$, pomorskie $2.4 \%$ and zachodniopomorskie $2.6 \%$. The group of voivodeships with the largest per capita GDP growth in 2008 an annual basis included: łódzkie 7.5\%, śląskie 7.4\%, podkarpackie $7.3 \%$, świętokrzyskie $7.1 \%$ and lubelskie $7.0 \%$. Three voivodeships from east Poland were amongst the leaders as well as two regions with a significant share of declining branches of industry. In observing a real convergence of the Polish economy as a whole it should be emphasised that simultaneously there is a process of development polaris- 
ation, which should be understood to means as deepening differences between particular regions. As despite Poland approaching the levels of European Union per capita GDP over the last twenty years, this process was not uniform in terms of the territory. The most dynamic were the voivodeships which include large urban centres - driving growth. Whereas it can be expected that the trend will continue, the European Union funds will be an actual counterweight for the tendencies observed thus far for growing disproportions in terms of regions. Detailed data pertaining to the progress of voivodeships in convergence in 2004-2008 are depicted in Figure 3.

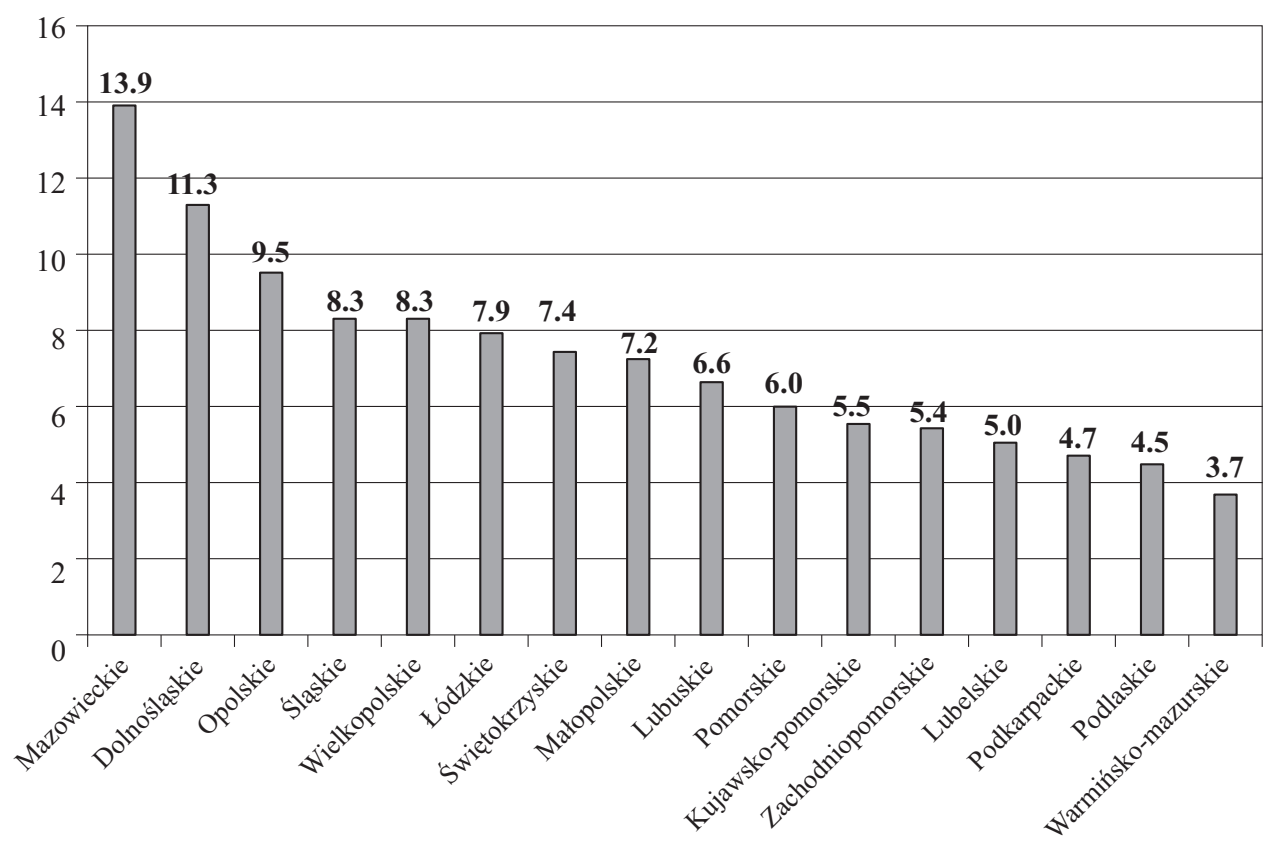

Fig. 3. Progress of polish voivodeships in 2004-2008 in real ceonvergence with EU-27 economic development level (reference year - 2003)

Source: Wplyw funduszy europejskich na gospodarkę polskich regionów i konwergencję z krajami UE. Raport 2010 (2010), Ministerstwo Rozwoju Regionalnego, Warszawa, p. 40.

To summarise it should be highlighted that the cohesion policy is having a real effect on the socio-economic situation in Poland and its regions. Poland is the largest recipient of this policy and as such is subject to scrupulous observation. Taking into consideration the fact that the time scale for the performance of structural funds and Cohesion Fund in our country is still not too excessive then their effects are visible in many aspects of socio-economic life. The results of analyses and research quoted in the article confirm that both developmental objectives and financial means within the scope of NPR 2004-2006 and NSFR 2007-2013 were programmed correctly. Taking into consideration the economic downturn experienced by Europe and Poland in recent years, it 
should be highlighted that the objectives of the programme documents are still current. Implementation of European Union's cohesion policy in Poland contributes to economic growth, which significantly exceeded the average growth rate of the EU. In 2004-2008 the growth rate in our country an average per annum was 5.4\%. As a result of the global recession economic growth in 2009 slowed down markedly falling to $1.7 \%$. Transfers of large amounts from the EU budget for the implementation of cohesion policy in Poland played a significant role on the socio-economic development in the country, at the same time alleviating the effects of the global financial and economic recession. The estimates carried out by the Ministry of Regional Development on the basis of econometric models show that on average, in 2004-2009 GDP growth was higher on account of the use of European funds by approx. $0.5 \mathrm{pp}$. During the course of both EU financial perspectives in Poland, or 2004-2006 and 2007-2013, in total the available finds amounted to 80.1 billion euro. The undertaken investments within the scope of infrastructure development and direct business support should start to affect investment activation in Poland, at the same time leading to increased gross fixed assets expenditures and improved investment rates. Research conducted by the Managing Authority (MRR) shows that support from community sources will allow for a yearly increase in growth by an additional 4-5 pp, increase in the gross expenditures on fixed assets and more investments in 2014 by more than $30 \%$ as compared with scenarios without the funds, or an investment rate higher by $4 \mathrm{pp}$. There is no way to overlook the fact that European funds create a noticeable increase in employment and falling unemployment. European intervention in the time horizon in question also has, albeit limited, influence over the sectoral structure of Polish economy. In 2004-2009 larger changes occurred in the sectoral structure of the employed that in the structure of the created GDP. Small effects of the funds were also reported on the increase of the dominant share in the economy of the services industry and a significant decrease of in the share of agricultural sector. The industrial sector exhibited stability with a slight tendency for growth in terms of gross added value. It should also be noted that the funds transferred to Poland form the European Union budget affect the condition of public finances. In the short run that may constitute one of the reasons for the worsening situation in the public finances sector, however in the longer run they should contribute to a permanent improvement to the stability of public finances measured in terms of deficit in relation to GDP. Whereas in terms of territory, Polish regions as a whole, have decreased the developmental distance separating them from European regions, measured in per capita GDP. As was pointed out in this article, overall convergence of the Polish economy is occurring simultaneously with a polarisation of development. understood as deepening disproportions between the growth leaders and regions in east Poland and other economically weaker regions. Gradually, year on year, the growing EU funds support is providing significant growth impulses for the home economy, however there is no doubt that it will not replace the endogenous factor. In this context it is significant to create, make available conditions determining own developmental possibilities. Furthermore the implementation of cohesion policy contributed to the popularisation across the entire public sector of modern management standards and institutional convergence.

To conclude, it should be pointed out that the macroeconomic effects stemming from the implementation of the European Union cohesion policy in Poland also have 
a European dimension. As analyses of evaluation research shows that the European cohesion policy has more than just a redistributive nature, but on account of macroeconomic mechanism it yields economic benefits for the entire European Union, primarily in the form of additional exports to Poland developed as a result of implementing and the positive effects of structural funds. Thus, the cohesion policy has is significant in terms of the increase in the overall scale of public, pro-developmental structural expenditures, complying with the effectiveness criterion, meaning that it has a positive effect on the basic macroeconomic indicators (Sługocki, 2013: 338).

\section{Bibliography}

Babiak J. (2008), Wiedza i innowacyjność we współczesnej gospodarce, in: Fundusze europejskie a innowacyjność polskiej gospodarki, (ed.) J. Babiak, Warszawa.

Ciak J., Adamiak J. (2007), Zintegrowany Program Operacyjny Rozwoju Regionalnego jako instrument realizacji polityki regionalnej - doświadczenia samorzqdu województwa kujawsko-pomorskiego, in: Finansowanie rozwoju regionalnego, (eds.) J. Stacharska-Targosz, J. Szostak, Poznań.

Council Regulation (EC) No 1260/1999 of 21 June 1999 laying down general provisions on the Structural Funds, OJ L 161, 26.06.1999.

Council Regulation (EC) No 1264/1999 of 21 June 1999 amending Regulation (EC) No 1164/94 establishing a Cohesion Fund, OJ L 161, 26.06.1999.

Gorzelak G. (2007), Rozwój-region-polityka, in: Rozwój-region-przestrzeń, (eds.) G. Gorzelak, A. Tucholska, Warszawa.

Grosse T. G. (2004), Polityka regionalna Unii Europejskiej. Przykład Grecji, Włoch, Irlandii i Polski, Warszawa.

Księżopolski K. M. (2011), Bezpieczeństwo ekonomiczne, Warszawa.

Narodowe Strategiczne Ramy Odniesienia 2007-2013 wspierajace wzrost gospodarczy i zatrudnienie. Narodowa strategia spójności (2007), Ministerstwo Rozwoju Regionalnego, Warszawa.

National Development Plan 2004-2006 (2003), Council of Ministers, Warsaw.

Raczkowski K. (2012), Percepcja bezpieczeństwa ekonomicznego i wyzwania dla zarzqdzania nim w XXI wieku, in: Bezpieczeństwo ekonomiczne. Wyzwania dla zarzqdzania państwem, (ed.) K. Raczkowski, Warszawa.

Regional growth in Europe. Territorial cohesion and EU budget overview (2009), EoRPA 2/2009 Reports, Warsaw.

Sługocki W. (2013), Polityka regionalna Unii Europejskiej a rozwój polskich regionów - studium przypadku, Zielona Góra.

Sługocki W. (2008), Polityka spójności Unii Europejskiej w Polsce. Dylematy i wyzwania, in: Wokót współczesności. Politologia. Prawo. Ekonomia, (eds.) Z. Dobrowolski, W. Sługocki, Zielona Góra.

Strategia Rozwoju Kraju 2007-2015 (2006), Ministerstwo Rozwoju Regionalnego, Warszawa.

Wpływ funduszy europejskich na gospodarkę polskich regionów i konwergencję z krajami UE. Raport 2010 (2010), Ministerstwo Rozwoju Regionalnego, Warszawa.

Żurkowska K. (2011), Bezpieczeństwo ekonomiczne, text prepared for the Modern Security Problems Panel, the Foundation Lech Wałęsa Institute, Warszawa. 
Żukrowska K. (2013), Ekonomia jako sfera bezpieczeństwa państwa, in: Interdyscyplinarność nauk o bezpieczeństwie, (eds.) K. Raczkowski, M. Żuber, K. Żukrowska, Warszawa (monograph manuscript).

\begin{abstract}
The article presents the Polish experience resulting from implementing European Union's cohesion policy in 2004-2006 and some experiences as well as the effects of funds from the European budget in 2007-2013. The effects of structural funds implementation on the development of Polish regions was is also presented in a synthetic manner, including their effect in the socio-economic situation in Poland as a whole. Issues pertaining to the influence of European intervention into the elimination of disproportions between Poland and the richer EU states have are also touched upon. The last part of the work mentions the role of funds from the EU budget in cushioning the effects of the economic downturn.
\end{abstract}

\title{
POLITYKA SPÓJNOŚCI UNII EUROPEJSKIEJ A BEZPIECZEŃSTWO EKONOMICZNE POLSKI
}

\section{STRESZCZENIE}

W artykule zaprezentowano polskie doświadczenia związane z implementacją polityki spójności Unii Europejskiej w latach 2004-2006, a także doświadczenia i efekty wykorzystania funduszy europejskich $w$ ramach budżetu na lata 2007-2013. Efekty jakie fundusze europejskie przyniosły rozwojowi polskich regionów, zostały zaprezentowane w syntetyczny sposób, z uwzględnieniem ich skutków dla sytuacji społeczno-ekonomicznej. 
